Alejandro Rodríguez Díaz del Real

\title{
Frankistična vstaja kot oživitev rekonkviste: analiza "remedievalizacije»
}

\begin{abstract}
IZVLEČEK
Avtor $v$ članku opozarja na poglavitni razlog za vojaško vstajo proti republikanski oblasti v Španiji, ki je bil po mnenju konzervativnih delov španske družbe, predvsem vojske in katoliške hierarhije, $v$ tem, da republika spreminja bistvo Španije. Nasprotno so republikanci svojo politiko razumeli kot modernizacijo Španije. Vojaška vstaja proti republikanskim oblastem se je začela v severni Afriki (v Melilli) 17. julija 1936. Konec septembra istega leta je v pastoralnem pismu škof Salamanke državni udar blagoslovil in spopad označil za pravično, za križarsko, vojno. Vojaški vstajniki so za svojo vzeli rdečerumeno zastavo, ki jo je konec 18. stoletja uvedel Karel III. Burbonski. Skušali so razviti tudi lasten koncept voditelja - Führerja, t. i. teorijo kavdiljizma, ki se je ujemala z doktrino nemške NSDAP. Parlamentarno demokracijo in pravno državo so zavračali kot obsojanja vredna simptoma liberalnega obdobja. Frankistična država je svoj ideološki naboj crpala v falangizmu in nacionalsindikalizmu. Franco je sam verjel v svoje božje poslanstvo. Ko je bilo aprila 1939 vojne konec, se je začelo težko povojno obdobje, ki se ga veliko še živečih spominja kot obdobja, ki je bilo hujše od same vojne.
\end{abstract}

Ključne besede: Španija, vojaški udar, Falanga, Franco, državljanska vojna

\section{ABSTRACT \\ FRANCOIST UPRISING AS A REVIVAL OF THE RECONQUISTA: ANALYSIS OF "REMEDIEVALISATION"}

In his article the author emphasises the main reason for the military uprising against the Republican authorities in Spain. In the opinion of the conservative parts of the Spanish society, especially the military and the Catholic hierarchy, the main reason was that the republic was altering the essence of Spain. On the contrary, the Republicans understood their politics as the modernisation of Spain. The military uprising against the Republican authorities started in North Africa (in Melilla) on 17 June 1936. In the end of September of the same year, the Bishop of Salamanca blessed the coup d'etat in his pastoral letter and designated the conflict as a righteous crusade. The military rebels adopted the red and yellow flag, introduced by Charles III of Bourbon at the end of the $18^{\text {th }}$ century. They also tried to develop their own concept of a leader - a Führerthe so-called theory of caudillismo, which went hand in hand with the doctrine of the German

* lekt., Filozofska fakulteta, Univerza v Ljubljani, Aškerčeva 2, SI-1000 Ljubljana, alejandro. rodriguez@ff.uni-lj.si 
NSDAP. They rejected parliamentary democracy and the rule of law as condemnable symptoms of the liberal period. The ideological momentum of the Francoist state was mostly based on falangism and national syndicalism. Franco himself believed in his divine mission. When the war ended in April of 1939, a difficult post-war period began. Many of the people who are still alive remember it as a period worse than the war itself.

Keywords: Spain, military coup, Falange, Franco, civil war

Uvod: druga republika kot žalitev bistva Španije

Poglavitni razlog za vojaško vstajo proti republikanskemu režimu, ki je prišel na oblast po občinskih volitvah 12. aprila 1931, in ki je nato leta 1936 privedla do španske državljanske vojne, je bilo trdno prepričanje najbolj konzervativnih delov družbe, predvsem vojske in katoliške hierarhije, da republika spreminja bistvo Španije. Republikanci pa so - nasprotno - svoj projekt razumeli kot modernizacijo Španije, ali z besedami Ortege y Gasseta, evropeizacijo. Dejansko je Druga republika z ustavo, sprejeto 9. decembra 1931, uvedla reforme, ki so imele veliko gospodarsko, družbeno in kulturno težo, kot so bile agrarna reforma, enakost med spoloma, ločitev zakonske zveze, decentralizacija države, da bi ugodili zahtevam Katalonije, Baskije in Galicije, progresivna vsesplošna dostopnost šolstva itd. Španijo so želeli približati svojim evropskim sosedam, zlasti Franciji, ker je bila zaostalost Španije v primerjavi z drugimi tako očitna, da jo je bilo že težko spregledati in jo sprejemati. Veleposestniki, velika buržuazija, pomemben del kmečkega prebivalstva, katoliška hierarhija in vojska so v omenjenih reformah videli tako predajo komunizmu, ki so se ga bali, kot začetek kolektivizacije lastnine, kar so imenovali sovietizacija. V letu 1937 so nekatere vesti, ki so prehajale iz republikanskega na nacionalno ali frankistično območje, kot tudi ukinitev denarja v nekaterih aragonskih agrarnih skupnostih ${ }^{1}$ (tovrstni primeri so se zgodili že leta 1933), povzročili pravo osuplost med premožnimi družbenimi razredi na obeh straneh, ki so se nagibali k temu, da podprejo nov, frankistični red, ki se je predstavljal kot garant zasebne lastnine in varuh reda in zahodne civilizacije pred »hordami azijskih komunistov «. ${ }^{2}$

Ob razpravljanju o Drugi republiki velikokrat pozabimo, da ne gre za enovito obdobje, pač pa za vedno bolj očitno radikalizacijo obeh taborov in naraščajočo polarizacijo družbe, vse dokler ta ni postala nevzdržna in je leta 1936 vodila v dokončni dramatični prelom. Za prvo, konstitutivno fazo republike, od prihoda antimonarhističnih strank na oblast pomladi leta 1931, sprejetja nove republikanske Carte Magne decembra istega leta, in celo do volilne zmage desnice leta 1933, je bila

1 Jesús Alonso Millán, La guerra total en España (1936-1939) (Google Libros, 2013), 262.

2 Ángel Viñas, "Franco y la subversión de la memoria, "v: España en la memoria de tres generaciones. De la esperanza a la reparación, ur. Julio Aróstegui (Madrid: Editorial Complutense y Fundación Largo Caballero, 2007), 114. 
značilna relativna zmernost, čeprav so bile vedno bolj vidne posledice mednarodne gospodarske krize, Velike Depresije. Od konca leta 1933 do zmage Ljudske fronte (Frente Popular) leta 1936 so vladajoče konzervativne stranke skušale spodnesti republiko, kljub temu da je bil takratna državna ureditev republika, zato se ta druga faza zgodovinskega obdobja imenuje dvoletje odstopanj od doseženega, konzervativno ali črno dvoletje. Že leta 1932 je bil izveden poskus državnega udara proti republiki, tako imenovana Sanjurjada, ${ }^{3}$ vendar je Azañeva vlada poskus zadušila, ker jo je obveščevalna služba o nameri dela vojske pravočasno obvestila. Že desetletja je bil Azaña eden glavnih zagovornikov republike, kot so bili to že od leta 1930 Ortega y Gasset, Marañón in Pérez de Ayala. Z znamenito izjavo, da Španija ni več katoliška, ${ }^{4}$ si je nakopal nenaklonjenost širokih slojev španske družbe, ki je bila še vedno preveč tradicionalna in tradicionalistična, da bi lahko sprejela tako jakobinsko laicistično ustavo, kot je bila ustava iz leta 1931, katere tretji člen se je dobesedno glasil: „Španska država nima uradne veroizpovedi«. ${ }^{5}$ Te besede so samo prilile olja na ogenj, kajti le mesec dni po razglasitvi republike so zagoreli samostani.

Versko vprašanje je bilo zelo zapleteno in nedvomno najbolj pereče, ko skušamo razumeti, zakaj so se duhovščina in najvišji družbeni sloji v Republiki počutili, kot da so potisnjeni v kot. Nova država pa je ta korak storila, ker je želela: ukiniti monopol Katoliške cerkve na področju izobraževanja, posledično ukiniti indoktrinacijo in modernizirati družbo z jasno ločitvijo Cerkve in države, kot je to storila velika vzornica Francija.

Drugo pereče vprašanje pa se je nanašalo na sicer staro zahtevo Katalonije po statutu o avtonomiji. Azañeva vlada je na to željo kaj kmalu odgovorila, saj so že novembra 1932 razpisali prve katalonske volitve v zgodovini v skladu s tako imenovanim Statutom iz Nurije, ki ga je sprejel španski parlament.

V razglasitvi, najprej katalonske republike 14. aprila 1931 in nato še katalonske države na začetku oktobra 1934, sta desnica in vojska prepoznali separatizem kot drugo veliko grožnjo tradiciji, v tem primeru sveti enotnosti Španije. Katalonskemu Statutu avtonomije je le za krajši čas sledila baskovska avtonomnost, ki bi ji sledila tudi galicijska, če ne bi prišlo do vojne.

3 General José Sanjurjo je kot Francisco Franco sodeloval v maroški vojni, kjer si je prislužil vzdevek lev Rifa. Vrhovno sodišče ga je zaradi vojaške vstaje obsodilo na smrtno kazen (24. 8. 1932), vendar je dan kasneje predsednik republike Niceto Alcalá-Zamora spremenil smrtno kazen v dosmrtno ječo. 27. avgusta je bil odpuščen iz vojske. Ob menjavi oblasti leta 1933 je bil pomiloščen, kljub temu da je imel Alcalá-Zamora velike pomisleke. Iz pregnanstva v Lizboni je koval zaroto proti Republiki in sodeloval v državnem udaru julija 1936. Tri dni kasneje je umrl v letalski nesreči.

4 El Sol, 14. 10. 1931.

5 Naj opozorim na nasprotje med odkritim laicizmom republikanske ustave, ki je bila sprejeta dva meseca po tem, ko je Azańa izrekel omenjeno izjavo v parlamentu, in brezkonfesionalnost ustave iz leta 1978, ki isto zadevo pojasnjuje kar v treh odstavkih 16. člena: »16.1. Posameznikom in skupnostim je zagotovljena ideološka in verska svoboda ter svoboda bogoslužja [...] pri tem je edina dopustna omejitev ta, ki je potrebna za ohranitev javnega reda, ki ga ščiti zakon. 16.2. Nihče se ni dolžan opredeliti glede svojega ideološkega, verskega ali drugih prepričanj. 16.3. Nobena veroizpoved ni državna. Javni organi upoštevajo verska prepričanja španske družbe in zato posledično sodelujejo s Katoliško cerkvijo in drugimi veroizpovedmi.« 
$\mathrm{Na}$ tretjem mestu je družbeno vprašanje, morda najpomembnejše, ki je v obdobju vedno slabšega položaja svetovnega gospodarstva postajalo vedno bolj pereče. Kmetje, dninarji, industrijski delavci in drugi, zgodovinsko marginalizirani delavci, so zelo veliko pričakovali od Druge republike, njihova pričakovanja pa so se razblinjala sorazmerno z rastjo krize. Eksplozivnost nekaterih dogodkov, kot je bilo nasilje v Casas Viejas, ${ }^{6}$ je globoko načelo zaupanje in zamajalo predvsem republikansko-socialistično koalicijo, ki jo je vodil Manuel Azańa v njeni prvi, zmerni fazi. Vlado sta napadali tako desnica kot levica, kar je prispevalo $\mathrm{k}$ volilnemu polomu levice novembra 1933. Ko je prišla na oblast Španska konfederacija avtonomnega desničarskega krila (CEDA, Confederación Española de Derechas Autónomas), pa ta ni imela nikakršnega predsodka, da ne bi izvedla eno najbolj krvavih represij proti neki revoluciji, kar jih je poznala Evropa: zatrtje revolucije v Asturiasu leta 1934. Dogodek so dramatično poimenovali kar Rdeči oktober. Tam so uporabili špansko vojsko iz Afrike, posebne enote kolonizacije, kjer je imel Franco priložnost pokazati svoje cenjene vojaške vrline, ki jih Preston imenuje ledena krutost (gélida crueldad). Njegova strategija je bila zelo premišljena:

Osrednji simbol vrednot desnice, ki jim je bil zvest, je bila rekonkvista Španije iz arabskih rok. Ker je dvomil, da bodo rekruti, ki so prihajali iz delavskega razreda, pripravljeni streljati na španske delavce, in ker ni želel prispevati k širitvi revolucije, kar bi se najbrž zgodilo, če bi uporabil vojake iz garnizij, ki so se nahajale na polotoku, saj bi jih oslabil, je brez predsodkov pripeljal maroške plačance, da so se borili v Asturiasu, edinem delu Španije, kjer polmesec nikoli ni zavladal. Prav nič protislovno se mu ni zdelo uporabiti Maročanov, enostavno zato, ker je obravnaval levičarske delavce $\mathrm{z}$ enakim rasnim zaničevanjem kot plemena Rifa. »Ta vojna je vojna za meje«, je komentiral dogodke nekemu novinarju, »in fronte so socializem, komunizem in vse možne oblike, ki napadajo civilizacijo, da bi jo nadomestile z barbarstvom «. ${ }^{7}$

Treba je bilo napasti republikanske vrednote, ki so po prepričanju ultradesne ideologije grozile civilizaciji, pa čeprav so bile, kot je bilo moč videti, njihove metode celo bolj okrutne od tistih, značilnih za domnevno barbarstvo, ki so ga želeli preprečiti. Pri tem je bilo ključno brezčutno delovanje frankistov, za kar je bil Franco (in ostali) nedvomno izurjen v času vojaškega usposabljanja v maroški vojni, zaradi česar je lahko asturijske rudarje, sonarodnjake, oropal njihovega statusa rojakov in jih obravnaval kot tujce ali dejansko protišpanske elemente ter jih zato kruto zatrl z

6 Dne 9. januarja 1933 je prišlo v španskih glavnih mestih do upora anarhistov. Ta je v Barceloni doživel polom in na drugih vzhodnih območjih pravzaprav ni dosegel svojih ciljev, ker je bil hitro zatrt. V Andaluziji je bil intenzivnejši, predvsem v Utreri (Sevilli), pokrajini Cádiza, kjer je nekaj dni kasneje nasilje zahtevalo največ žrtev. V Casas Viejas, blizu mesta Medina Sidonia, so anarhisti do smrti ranili narednika in gardista civilne garde. Odgovor vlade je bila usmrtitev petindvajsetih kmetov. Izgredi policije so povzročili velik družbeni pretres in zadali hud udarec ugledu predsednika Manuela Azañe. - Atlas cronológico de la Historia de España (Madrid: Real Academia de la Historia / SM, 2008), 344.

7 Paul Preston, Franco (Barcelona: Grijalbo, 1994), 138. 
vojaki, ki so se bili v gorovju Rifa navajeni boriti do smrti. Pet let kasneje, leta 1939, si je Kavdiljo za svojo osebno stražo ali de corps izbral eksotične jezdece »Mavrske garde« in tako svojim najbolj reprezentativnim potovanjem v Rolls Roycu dal pridih orientalskega paše, v skladu s tiranijo, ki je celotno Španijo obarvala s krvjo, saj se je znebil vsakega nasprotnika kot tudi samega Joséja Antonia Prima de Rivere, ki so ga najprej zanikali, nato poveličevali. Neizprosno zatrtje asturijske revolucije z vojaki iz Maroka je bil precedans, kajti med vojaškimi vstajniki leta 1936 so pomembno vlogo ponovno odigrali t. i. afrikanisti, vojaki, ki so si kariero ustvarili predvsem med španskimi kolonialnimi vojaškimi silami v današnjem Maroku. Tako Millán Astray, ki je leta 1920 ustanovil španski »Tujski regiment" (kasneje poimenovan Legija ${ }^{8}$ ), kot številni drugi vojaki, ki so podprli izbruh državljanske vojne (Franco, Cabanellas, Sanjurjo, Queipo de Llano in Mola), so se v dvajsetih letih ${ }^{9}$ bojevali v takratnem španskem protektoratu Maroku. Sloveli so po svoji prekomerni ambicioznosti in bili so obsedeni z junaštvom.

Dejansko je bil afrikanizem, ki so ga takrat razumeli kot "uveljavitev modernih idej nad barbarstvom, ki prevladuje v Afriki «, ${ }^{10}$ povezovalni element med člani novonastale kaste ali klana, saj so imeli skupno izkušnjo boja v Maroku. Njihovi odnosi so si bili tako blizu, da je šlo pravzaprav za napol družinske ali skoraj plemenske odnose. Pomembno so vplivali na izbruh državljanske vojne in imeli so celo pomembnejšo vlogo kot italijanski fašizem ali nacizem, kot je poudaril Nerín. ${ }^{11}$ Tako državni udar 17. in 18. julija 1936 ni bil samo začetek vojne, pač pa predvsem vrh dolgoletne konspiracije proti temu, kar so imeli za izdajo naroda. Zato ne preseneča, da so del Španije, kjer so zmagali vojaški vstajniki proti Drugi republiki, hitro poimenovali nacionalni tabor.

\section{Prikaz vojaške vstaje kot odrešitve}

Zaradi opisane vloge t. i. afrikanistov bolje razumemo, zakaj se je vojaška vstaja začela prav v severni Afriki, v Melilli, popoldan 17. julija 1936. Sprožil jo je uboj opozicijskega poslanca Joséja Calva Sotele (13. julija) kot odgovor na uboj, ki se je

8 V Špansko legijo so bili vključeni pretežno Španci (za razliko od francoske Légion Étrangère, v vrstah katere so bili predvsem tujci). Vanjo so se vključevali zaradi avanturizma in dobrega zaslužka. Bojevali so se zunaj polotoškega ozemlja in so bežno spominjali na profil drugorazrednih konkvistadorjev, ki so v 16. st. odhajali v Ameriko. Legionarji so kmalu zasloveli kot eden najstrašnejših delov španske vojske, ker je bilo zanje značilno navdušenje nad temačnostjo, ko so se v dokaz svoje požrtvovalnosti, poguma in možatosti bahavo spogledovali z nevarnostjo. To ponazarja tudi naslov njihove najbolj znane pesmi: Moja nevesta je smrt.

9 Gustau Nerín, La guerra que vino de África (Barcelona: Crítica, 2005), 27.

10 Obča ilustrirana enciklopedija "Espasa" (Enciclopedia Universal Ilustrada "Espasa»), ki jo navaja Nerín, La guerra, 24. Navaja tudi Moderni španski slovar (Diccionario del Español Actual), ki vsebuje tudi opredelitev termina: „vodja ali častnik, ki se je izuril v operacijah v Afriki« v jasnem nasprotju z opredelitvijo slovarja Španske kraljeve akademije (DRAE), ki pravi: »Oseba, ki se ukvarja s študijem in razvojem zadev, ki se nanašajo na Afriko«; ali v slovarju Inštituta za katalonske študije (Diccionari de l'Institut d'Estudis Catalans): "Zagovornik kulturnih vrednot in interesov Afričanov, predvsem črnih Afričanov«.

11 Nerín, La guerra, 27. 
zgodil dan pred tem, ko je bil umorjen pripadnik socialističnih milic José Castillo, ki so ga po mnenju Gibsona (1986) ubili karlisti, medtem ko Preston (1986) meni, da so ga ubili falangisti. Na obeh pogrebih, ki sta potekala skoraj istočasno, je prišlo do hudih spopadov in bilo je veliko ranjenih. Izmenjava političnega nasilja med obema taboroma, ki je potekala že od pete obletnice Republike, je postajala vedno hujša. Kdo je odgovoren za začetek vojne, pa zgodovinarji niso enotni. Kdo nosi večjo odgovornost, republikanci ali frankisti, se sprašuje Trapiello, čigar odgovor je jasen: nihče si ni želel liberalne, zmerne in laične Španije, ker je prišel čas za Španijo, ki je morala biti ne republikanska in demokratična, pač pa fašistična ali komunistična. ${ }^{12}$ Prva smrtna žrtev vojne je bila prav Tretja Španija, ki je v delu Upor množic ( $L a$ rebelión de las masas) Ortege y Gasseta oznanila, da sta jo obe skrajnosti ugrabili. S sociološkega vidika je treba pojasniti, da se je tisto pomlad in poletje leta 1936 prebivalstvo razdelilo in polariziralo na dva povsem enaka dela. Lahko bi rekli, da gre za fenomen obejestranske odtujitve, kar je onemogočalo kakršnokoli vmesno držo ali držo zmerne nevtralnosti. Ozračje v obeh taborih se je naelektrilo. ${ }^{13} \mathrm{Z}$ mesiansko propagando pa so sovražnika satanizirali. Unamuno je raje govoril o skupnem samomoru kot o državljanskem spopadu. ${ }^{14}$ Zaradi te kolektivne histerije so lahko človeka na ulici napadli zgolj zato, ker je bil oblečen v obleko in je nosil kravato. ${ }^{15}$ Filozofa Ortega y Gasseta, ki se je predano zavzemal za uvedbo republike, ${ }^{16}$ vendar je sčasoma postajal razočaran, ko je odkrival resne razpoke v njenem sistemu, so julija 1936, nekaj dni po vojaškem prevratu, na njegovem domu v Madridu obiskali nekateri njegovi študentje, oblečeni kot delavci, v modrih delovnih pajacih in z orožjem za pasom, goreče pripravljeni na antifašistični boj. K profesorju so prišli po moralno podporo. Podpisal naj bi sporočilo v podporo Republike. Ortega jih je zavrnil. ${ }^{17}$ Kasneje je pojasnil, da niti mrtev ne bi podpisal dokumenta ob prisotnosti orožja. Prav te vmesne drže okoliščine državljanske vojne niso dopuščale. Ortega je, preden je resno zbolel, nazadnje podpisal podoben dokument in kmalu zatem odšel iz Španije. Bil je vidno postaran in ni prav dobro vedel, katera stran bi ga lahko dala ubiti. ${ }^{18}$

Enrique Pla y Deniel, takratni škof Salamanke in kasneje nadškof Toleda, je v svojem pastoralnem pismu Obe mesti (Las dos ciudades) z dne 30. septembra 1936,

12 Andrés Trapiello, Las armas y las letras. Literatura y guerra civil (1936-1939) (Barcelona: Destino, 2011), 43.

13 Veliko avtorjev uporablja metaforo naelektrenosti, na primer tudi Trapiello, ibid., 46: „Ozračje je postajalo naelektreno."

14 Vojna se je šele dobro začela, ko je Unamuno že postavil točno diagnozo te hude bolezni: »Ne borijo se eni Španci proti drugim Špancem (ne obstaja anti-Španija), pač pa se bori celotna Španija, ena, proti sami sebi. Skupinski samomor.« Kot da bi Unamuno govoril o svoji lastni družini. Dva njegova otroka sta se borila v republikanskih rovih, on pa na strani nacionalistov. - Ibid., 53.

15 Raymond Carr, España 1808 - 1975 (Barcelona: Ariel, 2007), 628.

16 V svojem slavnem članku »Napaka Berenguer " (El Sol, 15. 11. 1930) je izjavil, da je treba uničiti monarhijo - Španci, vaša država ne obstaja! Zgradite novo! Delenda est Monarchia, februarja 1931 pa je skupaj z Gregoriem Marañónom in Ramónom Pérezom de Ayalo ustanovil Skupino v službi Republike (Agrupación al Servicio de la República).

17 Jordi Gracia, José Ortega y Gasset (Madrid: Taurus, 2014), 513.

18 Ibid., 518. 
katerega navdih je bil Sveti Avguštin, blagoslovil državni udar in spopad kot pravično vojno, ki jo je označil za križarsko. Malo pred tem je med napredovanjem frankistov prišlo do enega najbolj črnih dogodkov, krvavega pokola v Badajozu (poleti leta 1936). Tam so maroški vojaki v areni za bikoborbe ustrelili na tisoče nedolžnih civilistov in tako ponovili barbarstvo iz leta 1934 v Asturiasu. To je bil povračilni ukrep za zaostritev republikanske protiofenzive, saj je ta pomenila hladni tuš za začetni Frankov optimizem, ${ }^{19}$ kajti načrtoval je, da bo zavladal večjemu delu polotoka v nekaj dneh ali tednih. Takrat, konec poletja leta 1936, pa je uvidel, da lahko boj traja še mesece, celo leta. ${ }^{20}$ Februarja 1937 je ponovno prišlo do klanja, ko so frankisti z italijansko pomočjo z morja in po zraku kruto napadli prebivalstvo Malage, ki je po obalni cesti bežalo proti vzhodu. Število civilnih žrtev je bilo najmanj dvakrat višje kot v Badajozu, če se opremo na Prestonove izračune. ${ }^{21}$ Kasneje pa je Legija Condor bombardirala še Gerniko, kar je bilo v očeh celotne mednarodne javnost povsem nesprejemljivo. Če se vrnemo k zagovoru vojne kot sodobne križarske vojne, se je omenjeno pastoralno pismo pojavilo v kontekstu prvih velikih množičnih in nediskriminatornih pobojev prebivalstva, ki bi jih danes označili kot zločine proti človeštvu. Španska Cerkev, se je v tem velikem krvavem vrtincu sistematično postavila na stran krvnikov, razen v Baskiji, ker je razumela baskovski nacionalizem in je bila blizu ljudem, razen tega pa je v svojih govorih zmanjševala pomen pobojev. Zaradi tega je imela težave z Vatikanom, ki je bil pod pritiskom jeznega svetovnega javnega mnenja. ${ }^{22} \mathrm{Z}$ besedami Hilari Raguer:

[...] if the creation or re-establishing of this Confessional State required the launching of a Civil War, then a Civil War would be launched. It would not be for the first time; this would be for the fourth time. In most of the contemporary nations that were by then constitutional monarchies or democratic republics, a reasonable balance between Church and State had been reached, but in comparison to them Spain was like a distant galaxy. ${ }^{23}$

19 Preston, Franco, 211.

$20 \mathrm{~V}$ intervjuju, ki ga je Franco dal konec julija severnoameriškemu novinarju Jayu Allenu v Tetuanu, je na vprašanje, koliko časa bo še trajalo pobijanje, odgovoril, da bo napredoval proti Madridu, dokler ga ne zavzame, in bo tako za vsako ceno rešil Španijo pred marksizmom [...] Allen ga je nato vprašal: "Ali to pomeni, da boste morali pobiti pol Španije?« Franco je z nasmeškom odgovoril: »Ponavljam, za kakršnokoli ceno«. Objavljeno v: The News Chronicle (od 29 julija do 1. avgusta 1936), cit. po: Preston, Franco, 196-97.

21 Tako nacionalisti kot Italijani so bili neusmiljeni. Mednarodni protesti niso bili tako močni kot v primeru poboja v Badajozu, ker je Franco ukazal, da ne sme noben vojni dopisnik vstopiti v Malago. Po bitki sta Queipo de Llano in Roatta poslala še motorizirano kolono, da je sledila tistim, ki so zapustili mesto in bežali po obalni cesti. Samo prvi teden so v samem mestu ustrelili skoraj štiri tisoč republikancev in množični poboji so se vrstili še mesece. Na tiste, ki so bežali iz Malage, so z morja streljali z minometi, iz zraka pa z mitraljezi in bombami. - Preston, Franco, 274.

22 Hilari Raguer, The Catholic Church and the Spanish Civil War (London, New York: Routledge, 2007), 228-30.

23 Ibid., 20. 
Španska cerkev je bila torej "oddaljena galaksija« tudi v očeh Vatikana, ki je vendarle od svojega prvega Koncila leta 1869/70 v številnih zadevah sramežljivo zavzel stališče modernizacije in prilagajanja. Pokazali bomo, da ta oddaljenost, ki pravzaprav pomeni nasprotovanje temu, da bi se Cerkev ločila od države, s svojim estetskim in propagandističnim idealom seže v sam srednji vek.

\section{Simbolična remedievalizacija in zgodovinski mit kot legitimacija nove države}

Zagovorniki državnega udara in invazijske ter očiščevalne vojne, ki se je sprevrgla v dolgotrajno in krvavo ideološko čistko, so v svojem diskurzu trdili, da se želijo ponovno približati zahodu. Koncept čistke je soroden dejanjem čistk, ki so jih nacisti izvajali v Nemčiji od leta 1933 dalje. Vzporedno je frankizem dejansko uvedel še prakso remedievalizacije v vojaškem spopadu, $\mathrm{v}$ katerem je odkrival vzporednice $\mathrm{z}$ bojem med kristijani in muslimani v času rekonkviste. Kljub odporu Madrida, ki se je strnil v bran mesta pod sloganom No pasarán in so ga frankisti podcenjevali, ter obetom, da bo osvajalska vojna trajala dolgo in se bíla ped za pedjo, pučisti niso želeli odlašati $\mathrm{z}$ organizacijo nove države. ${ }^{24}$ Zato so uvedli vrsto simbolov, ki so odražali ideale vojaškega prevrata in so jih samopoimenovali Vstajenje Španije. ${ }^{25}$ Med simboli, ki jih je posvojila nova totalitarna država, je bilo tudi mesto. Samo teden dni po državnem udaru so 24. julija 1936 pučisti razglasili mesto Burgos za glavno mesto oziroma generalštab nacionalističnih operacij. Burgos je postal sedež Zveze nacionalne obrambe (Junta de Defensa Nacional), ki je 29. septembra 1936 predala Francu vodenje države, malo preden so ga razglasili za generalisima in predsednika. V Burgosu so mu v ta namen 1. oktobra pripravili tudi razkošno vojaško parado. Ta datum je bil nato $\mathrm{v}$ obdobju diktature uradni nacionalni praznik (oponašanje režimov Osi), znan kot Kavdiljev dan (Día del Caudillo).

Izbor Burgosa kot prestolnice nikakor bil naključen. Mesto, znano pod imenom Glava Kastilje, prikliče spomine ne samo na rojstvo Kastiljske grofije in kastiljščine kot jezika, temveč predvsem na rekonkvisto $s$ Cidom. Tukaj ne gre za zgodovinsko osebo, o kateri vemo zelo malo, ampak bolj za literarno osebo, znano iz legende o Cidu Campeadorju, ki je bolje kot kdorkoli poosebljal figuro na konju, Jakoba, »ubijalca Mavrov« (Santiago "Matamoros«). Tako je na izbor Burgosa vplivala premišljena namera, da bi vzpostavili tisočletne paralelizme, ki bi lahko mitično upravičili vojaški prevrat. Zanimivo je, da Burgos šele od leta 2008 uradno ni več Prestolnica križarske vojne - naslov, je mestu podelil Franko leta 1961. ${ }^{26}$

Vojaški vstajniki so za svojo vzeli rdečerumeno zastavo, ki jo je konec 18. stoletja uvedel Karel III. Burbonski, in izkopali bojno sekiro proti pofrancozeni republikanski tribarvni zastavi, rdeči, rumeni in vijolični, ki je bila uzakonjena z republikansko

24 Carr, España, 643.

25 Cristina Gómez Cuesta, "La construcción de la memoria franquista (1939-1959): Mártires, mitos y conmemoraciones, « Studia Historica, Historia Contemporánea, št. 25 (2007), 87-123, tu 90.

26 Diario de León, 12. 2. 2008. 
ustavo leta $1931 .{ }^{27}$ Vsekakor pa je novi grb, ki so ga sprejeli kasneje, odražal skoraj programsko neoimperialistične ideale, ki jih je s silo vsiljeval frankistični režim. S tem je ponovno obudil simbole kraljev, sklicujoč se na zgodovinsko obdobje Zlate dobe, ki je bilo za frankistični patriotizem eno najodličnejših in vrednih posnemanja. Po Zlati dobi je »režim hrepenel, ker mu je predstavljal zgodovinski skupek slave in junaštev, za katerega dediča se je imel frankizem «. ${ }^{28}$ Civilno ali zidno republikansko krono je zamenjala kraljeva in grb je uokvirjal velik orel Svetega Janeza. Enak orel je bil na grbu katoliških kraljev, ker je bila Izabela Kastiljska zvesta častilka Svetega Janeza Evangelista. Pučisti so kazali jasen namen ponovne katolizacije in konfesionalnosti, obenem pa so povezovali državni udar z začetkom novega obdobja: ponovnega rojstva imperialne Španije. Dodali so še jarem in puščice, emblema Izabele in Ferdinanda, ter gordijski vozel, ki ga je katoliški kralj prevzel od epizode z Aleksandrom Velikim. In nazadnje, na grbu so bile zapisane besede Ena, Velika, Svobodna, ki so bile edini povsem nov falangistični element. ${ }^{29} \mathrm{Za}$ Prestona je falangistični simbol jarma in puščic, enako kot svastike ali fasces, preplet starega z modernim. Falangistična osnova je več kot očitna. Rafael Sánchez Mazas je leta 1927 napisal:

Nikoli nismo imeli boljšega grba. S svojim snopom puščic in arhaičnim jermenom je spominjal na domovino, »bogato z žetvami in heroji«, kot je sanjal Vergilij [...] V delih in dnevih Španije, v mladosti imperija, tu so simboli $[\ldots]^{30}$

Podobno Ernesto Giménez Caballero, tudi falangist, leta 1932:

Za Španijo je butara s sekiro obstajala, še preden jo je v svoj klobuk zapičil neki Ítalo Balbo. V svoj grb sta jo vključila naša katoliška kralja. [...] Ne potrebujemo sposojenih simbolov. Mi smo bili narod še pred novo in ponosno Italijo in prepotentno Nemčijo. Ena mala razlika štirih stoletij! ${ }^{31}$

Teoretiki režima so skušali razviti lasten koncept Führerja, tako imenovano »teorijo kavdiljizma«, ki se je ujemala z doktrino nemške NSDAP. ${ }^{32}$ Parlamentarno demokracijo in pravno državo so zavračali kot obsojanja vredna simptoma liberalnega obdobja. ${ }^{33}$ Poglejmo si naslednji primer pisateljice Marie Zambrano:

27 Tribarvnost seveda izvira iz Francoske Republike, republike par excellence. Vijolično barvo pa razlagajo z revolucijo astiljskih comunerosov, ki so menili, da so Karel V. in Burgundci vsiljivci in so za kraljico zahtevali Ivano v letih 1520-1522.

28 Zira Box Varela, "La fundación de un régimen. La construcción simbólica del franquismo" (doktorska disertacija, Universidad Complutense Madrid, 2008), 308.

29 Ibid., 309.

30 Ian Gibson, En busca de José Antonio (Madrid: Aguilar, 2008), 39.

31 Ernesto Giménez Caballero, Genio de España. Exaltaciones a una resurrección nacional. $Y$ del mundo (Barcelona: Ediciones Jerarquía, 1939), navedeno v: Gibson, En busca de José Antonio, 38.

32 Nationalsozialistische Deutsche Arbeiterpartei.

33 Preston, Franco, 362. 
Večkrat je bilo v kratkem času rečeno, da je liberalizem zastarel, da je njegov čas minil. Vendar v Zgodovini, v kulturnem življenju, ali samo v življenju, ne mine nič, da ne bi bilo ožeto v svoji zrelosti. V Zgodovini vse pusti svoj sok - velika pivka nektarja.

Kaj nam bo ostalo od liberalizma? Kaj bo kot pogašen pepel padlo z njenega velikega kresa? Raketa poleti v noč, za trenutek razsvetli zabavo in nato brez sledi pade; simbol sterilne lepote. ${ }^{34}$

V nasprotju z mlado Marío Zambrano, ki je te vrstice napisala leta 1930 v skeptičnem tonu, sovražnik ni izbiral. Reakcionisti, karlisti, falangisti ali nacionalistični katoliki niso niti za trenutek podvomili vase, ne v svoje božje in odrešilno poslanstvo, ko so v svojem razumevanju sveta poveličevali smrt, pohabljenje in žalovanje. Tako vsaj ga je razumel Unamuno, ko je resno spravil v nevarnost svoje življenje, rekoč:

Ravnokar sem slišal nekrofilen in brezsmiselen krik Naj živi smrt! [...] General Millán Astray je invalid [...] Vojni invalid. Tudi Cervantes je bil. Vendar skrajnosti ne postavljajo pravil. Na žalost je danes v Španiji preveč invalidov. In če nam Bog ne bo pomagal, jih bo kmalu še več. Zaboli me ob misli, da lahko general Millán Astray določa pravila psihologije množic. Invalid, ki mu manjka Cervantesova duhovna veličina, možatost in celovitost človeka (ne superčloveka) kljub temu, da je bil pohabljenec. Dejal sem, da gre za invalida, ki mu manjka duhovna superiornost, zato začuti olajšanje, ko vidi, kako se okoli njega povečuje število pohabljencev. [...] Millán Astray bi si želel ustvariti novo Španijo po svoji podobi. Zato bi si želel videti pohabljeno Španijo, kot je to nezavedno tudi povedal. 35

\section{Covadonga in poveličevanje srednjeveškega mita: rekonkviste}

Box Varela pojasnjuje:

Vojne okoliščine ob prvem praznovanju Kavdiljevega dneva so vstajnikom na pladnju prinesle nepričakovani dogodek: osvojitev Covadonge in s tem oblast nad ozemljem na severu. Sovpadanje tega dogodka z novim praznikom je pomenilo, da je bil slavljenec božji človek. Naključje, da je Kavdiljo na svoj dan lahko Domovini "podaril najlepše in najbolj dostojanstveno darilo imperialistične križarske vojne«, simbolično asturijsko svetišče, zibelko rekonkviste, je bil lahko samo dokaz več, da je bil Franco izbranec, dober in genialen človek, ki je vladal Španiji po božji volji. ${ }^{36}$

Kateri simbol bi bil ob Cidu, ki je predstavljal Francov alter ego, lahko sploh

34 María Zambrano, Horizonte del liberalismo (Madrid: Ediciones Morata, 1996), 237.

35 Besede Miguela de Unamuna v avditoriju Univerze v Salamanki, 12. oktobra 1936 (Dan rase ali španskosti) pred Carmen Polo, Francovo ženo, škofom mesta (Pla y Deniel), rektorjem, falangisti, politiki, legionarji, profesorji etc. Krik generala Millana Astraya v odgovor na povedeno je več kot znan: "Smrt inteligenci«. Navedeno v: Trapiello, Las armas y las letras, 56.

36 Box Varela, La fundación de un régimen, 235. 
boljši od Covadonge, da bi puč ali križarska vojna lahko postala še eno veliko junaštvo v prisiljeni zgodovinski kontinuiteti? Bitka pri Covadongi leta 722 ni bila zelo pomembna, ker je bil to manjši spopad kralja-pastirja Pelaya. ${ }^{37}$ Kljub temu je nesporno, da je Covadonga skozi proces mitifikacije postala emblematični kraj, kjer se je začela rekonkvista. To je razumljivo, saj se je bilo v 19. stoletju treba opreti na tovrstne romantične zgodbe, ki so bile osnova nacionalizmu po okusu akademskih krogov, vedno nagnjenih $\mathrm{k}$ dobesednemu interpretiranju netočnih pozno srednjeveških kronik. Kakorkoli že, ponovno je mit in ne dolgočasna zgodovinska natančnost dal krila delirantnemu frankističnemu megalomanstvu, kar se odraža tudi v jeziku, polnem najbolj romantičnih nacional-historicizmov. Dopisnik časnika ABC Antonio Olmedo je, ko so frankisti iztrgali sveto jamo (katoliško svetišče Santa Cueva de Covadonga) iz rok rdečih Asturijcev, zapisal:

[...] Včeraj je španska vojska vzdignila svojo častito krvavo in bojno zastavo nad branik rekonkviste. [...] Zmagovalni napadalci nepriljudene in do zdaj neosvojljive gore [...] so iskali boljševiškega vodjo, ki je obljubil, da bo ponovil Pelayevo junaško dejanje, vendar ga ni bilo, Francovi vojaki ga niso našli. Našli niso niti [...] komunistične horde. Povsem razumljivo je, da so zbežali. Nimajo tistega bistvenega, da bi lahko ponovili junaštvo Kralja pastirja: vere.

Rdečim Asturijcem bi morala zadostovati učna ura iz Covadonge, da bi položili orožje, vendar temu ne bo tako, ker Moskva svojih mrtvih lakajev ne objokuje. [...] V Covadongi, kjer je Pelayo začel rekonkvisto, bi se lahko končala osvoboditev Asturiasa. [...] zdaj gre tudi za izpolnitev naloge rekonkviste [...] Covadonga je bila zavzeta ravno na Kavdiljev dan. Slovestnost slovesnosti. To vojno smo z razlogom vedno imenovali vojno simbolov. 38

»Vojna simbolov« je zahtevala na tisoče smrtnih žrtev, ${ }^{39}$ kot, na primer, v bitki pri Jarami, ${ }^{40}$ številne begunce, ljudi, ki so zbežali iz svojih domov, ujetnike in talce. ${ }^{41}$ Simbolizem je z meseci nedvomno še naraščal in se povezoval z najbolj vidnimi tragedijami, dokler ni dosegel nepredvidljive dimenzije kolektivne katarze, katarze krvi, lakote ter opustošenja, ki jo je spretno dirigiral totalitarni režim. Kot pravi García Cárcel:

37 Atlas cronológico de la Historia de España, 55.

38 ABC de Sevilla, 2. 10. 1937, 11.

39 Glede frankistične represije gl.: La Gran represión: los años de plomo de la posguerra (1939-1948) (Barcelona: Flor de Viento, 2009). Historia politica, 1875-1939 (Madrid: Ediciones Istmo, S.A., 2002), 388-292. O represiji republikancev piše, med drugimi, katoliški klasik Antonio Montero Moreno, Historia de la persecución religiosa en España (Madrid: Biblioteca de Autores Cristianos, 1998).

40 Bilo je 15000 mrtvih, od teh devet tisoč republikancev. - Atlas cronológico de la Historia de España, 352.

41 Carr, España, 648, navaja Documents of German Foreign Policy, št. 586, in pravi, "začetne represije so izvajali falangisti, stare desničarske skupine ipd. Kasneje pa so represijo izvajala sodišča. Tudi na republikanski strani je bil viden prehod od spontane do organizirane represije«. 
Frankizem je napisal uradno zgodovino Španije, ki jo je Stanley G. Payne krstil kot »Veliko zgodbo«: zmes med starimi identitetnimi romanskimi, gotskimi in indijanskimi referencami z referencami spomina celo na muslimanstvo, primerno prilagojeno takratnemu "marokizmu«. Bili so obsedeni s preseganjem pomena muslimanske Španije, špansko-arabskega bratstva, da bi pokazali sposobnost vplivanja španskega na muslimansko in ne obratno. Španski arabizem je vsekakor zelo pripomogel pri tej operaciji nacionalistične ponovne oborožitve. Velika zgodba je bila predvsem izvajanje eklekticizma glede na korenine identitete. ${ }^{42}$

Po drugi strani so bila za psihološko ofenzivo s premišljeno logiko smrti in vstajenja ključnega pomena frankistična bombardiranja s kruhom (npr. na Madrid, Barcelono, Alicante, Palamós, Mahón in Pollenso) oktobra 1938, ko so letala, celo letala Legije Condor, na izčrpano in sestradano prebivalstvo republikanskih mest metala vreče kruha, in celo cigarete, da bi jih demoralizirala in skušala tako doseči kapitulacijo njihove vojske. ${ }^{43}$

\section{Sklep}

Frankistična država je svoj ideološki naboj črpala v falangizmu in nacionalsindikalizmu, ki ga je ustanovil José Antonio Primo de Rivera skupaj z nacionalističnimi katoliki in vojaki ali requetéji navarskega karlizma. Franco je leta 1937 izvedel še en prevrat, udar znotraj samega državnega udara, da bi zedinil raznolike težnje znotraj nacionalnega tabora. S samoudarom, ki je bil povezan tudi z dejstvom, da je po bombardiranju Gernike veliko katolikov začelo dvomiti o legitimnosti in svetosti frankističnega cilja, si je Franco zagotovil vso oblast ne samo nad novo državo, pač pa tudi nad novo, edino stranko, Špansko falango in JONS-om. ${ }^{44}$ Navdihnil ga je Mussolinijev Gran Consiglio Fascista. Tako je aprila 1937 ustanovil Nacionalni svet FET-a ${ }^{45}$ in JONS-a, enotno stranko falangistov in karlistov, ki je vladala Španiji celo po Francovi smrti, do prvih demokratičnih volitev leta 1977. S tako nakopičeno oblastjo je ofenziva nacionalistov prešla v fazo popolnega uničenja sovražnika.

Franco je ob vsej svoji mogoči in nemogoči oblasti tudi sam verjel v svoje božje poslanstvo. Po zavzetju Santanderja 25. julija 1937, na dan Jakoba, zavetnika Španije, je Franco izjavil, »da mu je apostol na svoj praznik podaril zmago «. ${ }^{46}$ Novembra je z nekim francoskim novinarjem ponovno govoril o križarski vojni: »Ne gre za dr-

42 Stanley G. Payne, España. Una historia única (Madrid: Temas de hoy, 2008), v: Ricardo García Cárcel, La herencia del pasado. Las memorias históricas de España (Barcelona: Galaxia Gutenberg, 2011), 461.

43 Josep María Solé i Sabaté in Joan Villarroya, España en llamas. La guerra civil desde el aire (Madrid: Temas de Hoy, 2003), 215, 217-20.

44 Nacionalsindikalistične ofenzivne skupine (Juntas de Ofensiva Nacional-Sindicalista), ki jih je leta 1934 ustanovil Ramiro Ledesma Ramos.

45 Tradicionalistična španska falanga (Falange Española Tradicionalista), ki jo je oktobra 1933 ustanovil J. A. Primo de Rivera.

46 Preston, Franco, 355. 
žavljansko vojno, pač pa za Križarsko vojno ... Da, naša vojna je verska vojna. Mi, mi vsi, ki se bojujemo, kristjani in muslimani, smo božji vojaki in se ne bojujemo proti drugim ljudem, temveč proti ateizmu in materializmu «. 47 Propagandna služba pod vodstvom Dionisia Ridrueja je meseca decembra pripravila uprizoritev v samostanu Santa María la Real de las Huelgas v Burgosu. Člani zgoraj omenjenega Nacionalnega sveta so v kostumih iz 16. st. in v spremstvu bobnov in kornetov paradirali po razkošnih samostonskih dvoranah in križnih hodnikih ter pred marmorno podobo Kristusa in praporjem zgodovinske bitke Navas de Tolosa (1212) prisegali zvestobo Francu. ${ }^{48}$

Ko je bilo aprila 1939 vojne konec, se je začelo težko povojno obdobje. Sledilo je tako imenovano obdobje lakote, ki se ga veliko še živečih spominja kot obdobja, ki je bilo hujše od same vojne. $V$ tem posttravmatičnem kontekstu se je 20. novembra začela desetdnevna mrtvaška procesija z jasnimi srednjeveškimi potezami: preselitev ostankov Joséja Antonia Prime de Rivera iz Alicanteja v El Escorial. Pogrebni sprevod, ki je potoval čez opustošeno in črno Španijo, preplavljeno z bedo, med bolečimi ruševinami nedavnega bombardiranja, je bil načrtovan tako, da bi se za vedno vtisnil v spomin prisotnih. Krsto so ob baklah dan in noč nosili na ramenih falangisti, prostovoljci, in niso je smeli nikoli spustiti na tla. Preston meni, da je šlo še za enega od številnih pogrebov, katerih namen je bil živo ohranjanje sovraštva, porojenega v državljanski vojni. ${ }^{49}$ Vsako menjavo nosačev so pozdravili streli topov in zvonenje zvonov v vseh španskih mestih in vaseh, spremljali so ga parajoči kriki José Antonio, presente! (José Antonio, tukaj.). Ceremonija je posnemala bolečo in žrtveno estetiko Velikega tedna, ki je bil z velikim zanosom ponovno uveden v novi, pred kratkim ponovno osvojeni katoliški Španiji. Srednjeveški ples kot podaljšanje vojaškega spopada. Po krvi in ognju pokora, bolečina in objokovanje. Vse je bilo makiavelistično premišljeno. Franco bi namreč lahko leta 1936 zamenjal Joséja Antonia Primo de Rivera, ko je bil zaprt v Alicanteju, za kakšnega pomembnega republikanskega zapornika na nacionalnem ozemlju, vendar tega ni storil. Je pa nato na grozljiv način manipuliral z ustanoviteljem španskega falangizma, z njegovim mučeništvom, z njegovo smrtjo in prisotnostjo njegovega duha. Leta 1959 je celo preselil njegove posmrtne ostanke iz El Escoriala v pravkar končano baziliko v Valle de los Caídos (Dolino padlih), ki se nahaja nedaleč stran od El Escoriala, kjer počivajo habsburžanski in burbonski kralji in kraljice, novo ad hoc kostnico, v kateri naj bi nekoč skupaj počivali vsi njegovi. Valle de los Caídos so s potom in solzami gradili tisoči republikanskih zapornikov pod neizmernim, 150 m visokim križem, največjim na svetu. Novembra 1975 so Franciscu Francu že na smrtni postelji umetno podaljšali agonijo, da bi njegova smrt sovpadla z datumom smrti José Antonija Prima de Rivere, ki je tudi preminil 20. novembra. Ta podobnost je groteskni dokaz pravega kulta smrti, ki ga je negoval režim. Danes se na ta dan še vedno v Valle de los Caídos zberejo najrazličnejši frankisti, fa-

\footnotetext{
47 Ibid., 363.

48 Ibid., 363-64.

49 Ibid., 433.
} 
langisti, karlisti in reakcionarji, da bi se brez najmanjšega političnega dvoma v vlogo mavzoleja poklonili svojima herojema.

María Zambrano iz Malage je iz filozofske perspektive v izgnanstvu leta 1958 opisala mučeništvo, ki so ga trpeli njeni sodobniki kot generacijsko žrtev, to pa je umestila v neizbežno žrtveniško zgodovinsko strukturo družbe. Zgodovina je tragedija, še bolj tragična je zgodovina Zahoda: ${ }^{50}$

Kdor iz sebe naredi boga, se mora videti in se počutiti kot bog $\mathrm{v}$ odnosu do drugega, $\mathrm{v}$ drugem. In ker mu božja vrsta služi kot model, [...] zelo primitivna verska obdobja [...] zahtevajo žrtve, kajti samo s tem, da se dvigne nad žrtev ali nad skupino žrtev, si lahko nekdo, ki ni bog, ustvari iluzijo, da to je. [...] In ker nikoli ne more postati bog, so nenehno potrebne žrtve: brezštevilne žrtve. To je trenutek, ko je zgodovina en sam pomnožen zločin: en sam zločin v neomejenem številu. ${ }^{51}$

To ni edina digresija Zambranove v zvezi z državljansko vojno in frankizmom. Leta 1967 je napisala svoje edino gledališko delo Antigonin grob (La tumba de Antígo$n a)$, ki aktualizira mit in je močno prežeto $\mathrm{z}$ avtobiografskimi elementi. Zaradi izbire žanra, kot je tragedija, in s tematiziranjem španske državljanske vojne, je to dramsko delo eden od mejnikov ali nasprotje goreče retorike, ki je opravičevala križarsko vojno frankistov in španske katoliške cerkve; retorike, ki je bila živa vse do Francove smrti. Virginia Trueba pravi:

Državljanska vojna je stvarni oder, na katerem Zambrano izreče svojo jasno obtožbo vseh oblik nasilja in totalitarizmov, vključno z nasiljem manipulatorskega jezika, $s$ katerim oblastniki gradijo stvarnost in jo uzakonijo na način, da lahko potem opravičijo vsa svoja dejanja. ${ }^{52}$

Zelo znano delo Viktorja Klempererja ${ }^{53}$ je obravnavalo jezikovni vidik v tovrstnih režimih, ko je podrobno preučeval deformacijo nemškega jezika v letih nacionalsocializma; nedvomno je mogoče potegniti vzporednice $s$ španščino, vendar z dvema razlikama. Prvič, frankizem je že imel na voljo španske in avtohtone vire, iz katerih je lahko črpal, ko je uveljavljal določen jezik in mite, ki so ustrezali, kot smo pokazali, tako zgodovinski kot verski tradiciji. ${ }^{54}$ Drugič, jezikovna ideologizacija se v Španiji ni končala leta 1945 kot v Nemčiji, temveč je trajala do Francove smrti. Celo dlje, saj je razmah frankizma uspel ukoreniniti določene besede, njihove na novo podeljene pomene ali določene jezikovne fenomene, ki so se ohranili še po diktator-

50 María Zambrano, Persona y democracia (Siruela: Anthropos, 2011), 403-43.

51 Ibid., 425-26.

52 Uvod v: María Zambrano, La tumba de Antígona (Madrid: Cátedra, 2012), 85.

53 LTI - Notizbuch eines Philologen. Leipzig 1996.

54 „Španija, ki je evangelizirala polovico sveta; Španija, gorjača za nevernike, luč Trenta, meč Rima, zibelka svetega Ignacija ...; to je naša veličina in enotnost, nimamo druge." Marcelino Menéndez y Pelayo je zapisal te znane besede v epilogu dela Historia de los heterodoxos espańoles (1880-1882). 
jevi smrti. Ni bilo ostrega preloma, kot je bil to Entnazifizierung ali denacifikacija, kajti španska tranzicija $\mathrm{v}$ demokracijo je potekala ob sodelovanju $s$ frankizmom, ki je bil takrat že bolj tehnokratski kot fašističen in naklonjen reformam, vendar pa je kot dediščina ali konceptualna lastnina prežemal konzervativne stranke in vladajoče sektorje španske družbe.

$\mathrm{V}$ okviru razprav, ki so se porodile v 21. stoletju v zvezi s tako imenovanim zgodovinskim spominom (memoria histórica) v času Aznarjeve in Zapaterove vlade, so se začele analizirati travme in medgeneracijski prenos spomina na vojno, tudi z vidika socialne psihologije. 55

Po drugi strani García Cárcel ${ }^{56}$ v svojim delu kritizira zlorabo termina memoria histórica in predlaga uporabo besedne zveze v množini (s tem tudi pluralistično) zgodovinski spomini (memorias históricas), da bi poudaril, kako težko je poskusiti pisati o vzpostavljanju spomina za eno samo zgodovinsko obdobje, kot da v Španiji ne bi obstajalo še več kolektivnih travm in ne samo državljanska vojna.

Malo konfliktov kot ta usodna vojna lahko bolje ponazori dilemo med prometejskim in nezadržnim človeškim vzgibom, da bi izboljšal svoje življenjske pogoje v spreminjajočem se svetu in med nasilnim pobegom $\mathrm{v}$ srednjeveško in poenostavljeno preteklost, ravno zato, da bi nasprotovali tem človeškim vzgibom po spremembi in boljšem življenju, ki so se porajale celo stoletje.

Prevedla: Marija Uršula Geršak

\section{Viri in literatura}

Časopisni viri:

- ABC de Sevilla, 2. 10. 1937, 11.

- Diario de León, 12. 2. 2008.

- El Sol, 15. 11. 1930.

- El Sol, 14. 10. 1931.

Literatura:

- Alonso Millán, Jesús. La guerra total en España (1936-1939). Google Libros, 2013.

- Atlas cronológico de la Historia de España. Madrid: Real Academia de la Historia / SM, 2008.

- Box Varela, Zira. »La fundación de un régimen. La construcción simbólica del franquismo.« Doktorska disertacija, Universidad Complutense Madrid, 2008.

- Carr, Raymond. España 1808-1975. Barcelona: Ariel, 2007.

- García Cárcel, Ricardo. La herencia del pasado. Las memorias históricas de España. Barcelona: Galaxia Gutenberg, 2011.

- Gibson, Ian. En busca de José Antonio. Madrid: Aguilar, 2008.

55 Inmaculada Gómez Marín in José Antonio Hernández Jiménez, "Revisión de la Guerra Civil Española y la posguerra como fuente de traumas psicológicos desde un punto de vista transgeneracional, «Revista electrónica de psicoterapia, št. 5 (3) (oktober 2011): 473-91.

56 Njegov esej La herencia del pasado. Las memorias históricas de España (Dediščina preteklosti. Zgodovinski spomini na Španijo) je bil leta 2012 nagrajen z nacionalno nagrado za zgodovino Premio Nacional de Historia 2012. 
- Gómez Cuesta, Cristina. "La construcción de la memoria franquista (1939-1959): Mártires, mitos y conmemoraciones.« Studia Historica, Historia Contemporánea, št. 25 (2007): 87-123.

- Gómez Marín, Inmaculada in Hernández Jiménez, José Antonio. "Revisión de la Guerra Civil Española y la posguerra como fuente de traumas psicológicos desde un punto de vista transgeneracional.« Revista electrónica de psicoterapia, št. 5 (3), oktober 2011, str. 473-91.

- Gracia, Jordi. José Ortega y Gasset. Madrid: Taurus, 2014.

- Historia política, 1875-1939. Madrid: Ediciones Istmo, S.A., 2002.

- La Gran represión: los años de plomo de la posguerra (1939-1948). Barcelona: Flor de Viento, 2009.

- Montero Moreno, Antonio. Historia de la persecución religiosa en España. Madrid: Biblioteca de Autores Cristianos, 1998.

- Nerín, Gustau. La guerra que vino de África. Barcelona: Crítica, 2005.

- Preston, Paul. Franco. Barcelona: Grijalbo, 1994.

- Raguer, Hilari. The Catholic Church and the Spanish Civil War. London, New York: Routledge, 2007.

- Solé i Sabaté, Josep María in Joan Villarroya. España en llamas. La guerra civil desde el aire. Madrid: Temas de Hoy, 2003.

- Trapiello, Andrés. Las armas y las letras. Literatura y guerra civil (1936-1939). Barcelona: Destino, 2011.

- Viñas, Ángel. „Franco y la subversión de la memoria. V: España en la memoria de tres generaciones. De la esperanza a la reparación, ur. Julio Aróstegui. Madrid: Editorial Complutense y Fundación Largo Caballero, 2007.

- Zambrano, María. Horizonte del liberalismo. Madrid: Ediciones Morata, 1996.

- Zambrano, María. La tumba de Antígona. Madrid: Cátedra, 2012.

- Zambrano, María. Persona y democracia. Siruela: Anthropos, 2011.

Alejandro Rodríguez Díaz del Real

FRANCOIST UPRISING AS A REVIVAL OF THE RECONQUISTA: ANALYSIS OF "REMEDIEVALISATION"

\section{S UMMARY}

The main reason for the military uprising of the conservative parts of the Spanish society, especially the military and the Catholic hierarchy, was their firm conviction that the introduction of the Republic would alter the essence of Spain. The Republicans saw it as the modernisation of Spain. With the constitution, adopted on 9 December 1931, they introduced the reforms which had a great economic, social and cultural importance (decentralisation of the state, agrarian reform, gender equality, dissolution of marriage, etc.). They wanted to bring Spain closer to its European neighbours, especially France. On the contrary, the landowning aristocracy, the prominent bourgeoisie, an important part of the peasant population, the Catholic hierarchy and the military saw these reforms as the introduction of communism. Therefore already in 1932 an attempt at a coup d'état against the Republic, the so-called Sanjurjada, was carried out. The question of the decentralisation of the state and introduction of autonomy for Catalonia, Basque Country and Galicia were among the pressing issues of Spain. The proclamation of the Catalan Republic on 14 April 1931 and then also the Catalan State in the beginning of October 1934 was seen by the right wing and the military as separatism and thus as a great menace to tradition, to the "sacred unity of Spain «. The central symbol of the right-wing values was the Reconquista of Spain - a struggle against the Arabs, the Muslims on the Iberian Peninsula. Therefore the attack against the Republican values - which, in the opinion of the ultra-rightist ideology, represented a threat to civilisation itself - was understood as an expression of the Reconquista. The Bishop of Salamanca and later the Archbishop of Toledo, Enrique Pla y Deniel, thus blessed the coup d'état in his pastoral letter inspired by Saint Augstin in the end of September 1936, and designated the conflict as a crusade. In 1936 the so-called africanistas - soldiers who had made their careers in the Spanish colonial military force in what is today Morocco - once again assumed an important role among the military rebels against the 
"Republic«. As the rebels doubted that the recruits who came from the working class would be prepared to shoot at Spanish workers, they unscrupulously brought in Moroccan mercenaries. That explains why the military uprising against the legal and legitimate Spanish authorities started precisely in North Africa (in Melilla, in the afternoon of 17 July 1936). The defenders of the coup d'état and the invasive and cleansing war, which turned into a long and bloody ideological purge, claimed in their explanations that they wanted to approximate Spain to the West again. The concept of their purge was similar to the purges perpetrated by the Nazis in Germany after 1933. Simultaneously Francoism also introduced the practice of remedievalisation in the military conflict, which, in its opinion, resembled the battle between the Christians and the Muslims during the Reconquista. For example, General Franco as the leader of this "Reconquista" spoke to a French journalist in November 1937, and said the following about the crusade: "This is not a civil war, but a Crusade... Indeed, our war is a religious war. We, all of us, who are fighting, the Christians and the Muslims, are God's soldiers and we don't fight against other people, but against atheism and materialism.» 